\title{
COMPARATIVE ANALYSIS OF LINGUISTS' PROFESSIONAL TRAINING AT BRITISH AND UKRAINIAN UNIVERSITIES
}

\begin{abstract}
We have performed comparative analysis on professional training of linguists at British and Ukrainian universities at administrative and managerial, legislative, organizational and pedagogical, systemic, conceptual, socioeconomic levels. As evidenced above, British and Ukrainian systems of professional training of linguists differ significantly, but simultaneously they are similar to the trends in development. In the first place, the main difference is manifested in the content of curricula. Professional training of linguists in Ukraine is aimed primarily at professional orientation on the national (regional) labour market, comprehensive development of personality of future specialists, formation of harmonious development of both general and professional qualities. In British experience, this training is oriented toward the world labour market. In view of the above, it is expedient to update the content of curricula for linguistics, in particular, its focus on professional and researchbased training, taking into account the best practices of foreign experience, in particular British one. An important objective of Ukrainian higher education institutions is to improve quality of teaching professional and special disciplines, provide modern teaching materials, as well as attract foreign specialists to teaching. It is also worthwhile to encourage students to participate in work placements abroad, as it is the case with leading universities in Great Britain. Perspectives for further researches are seen in studying foreign experience in training linguists at leading European universities in order to justify the best aspects of such experience and therefore implement them into practice of professional training of linguists at Ukrainian universities.
\end{abstract}

Keywords: linguistics, linguist, comparative analysis, professional training, university, Ukraine, Great Britain.

\section{INTRODUCTION}

The 21 st century modifies the paradigm of awareness of the phenomenon of education in a global context. The states all over the world are making efforts to improve educational practices in primary, secondary and higher education through the prism of economic and social projects designed to promote the idea of a modern person who seeks personal and professional development. So, in 2005, Ukraine signed the Bologna Declaration and thus launched a new stage in the development of the national education system. The integration of Ukrainian higher education into the European Higher Education Area (EHEA) prompts the search for effective innovative ways of modernizing professional education. The internationalization of the system of higher professional education creates conditions for expanding the boundaries of international activities of universities, including development and implementation of double degree programmes and academic exchanges. This is especially important for professional training of linguists, since it is a prerequisite 
for its quality. In this regard, improvement of the content and organization of linguists' professional training becomes a topical direction of pedagogical researches.

\section{THE AIM OF THE STUDY}

The aim of the study is to perform comparative analysis of professional training of linguists at British and Ukrainian universities.

\section{THEORETICAL FRAMEWORK AND RESEARCH METHODS}

Theoretical framework of the research consists of works by N. Bidyuk (2013), Cunningham (2014), D. J. Edwards (1994), A. I. Gretchenko (2016), R. Hudson (2004), T. Tretko (2014). In addition, we have applied to such sources as the National Archive of UK legislation, Quality Assurance Agency and several Ukrainian electronic editions. Also we have used the information on linguistics curricula provided by Khnelnystkyi National University and Newcastle University to analyze the peculiarities of organization of linguists' professional training in both countries.

Comparative pedagogical analysis has been carried out in different directions in order to identify common and different approaches for the purpose of borrowing positive achievements and preventing mistakes in the process of modernizing professional training of linguists in Ukraine: administrative and managerial, legislative, organizational and pedagogical, systemic, conceptual, socioeconomic, etc. In our opinion, justification of positive ideas of British experience and their comparison with the traditions of national higher education will contribute to improvement of professional training of linguists.

\section{RESULTS}

Consequently, on the path to creation of European educational space, one of the fundamental issues that requires urgent resolution is the convergence of higher education systems. After all, each country formed her own national higher education systems, which are significantly different from similar systems in other countries.

Thus, we consider it necessary to analyze the peculiarities of higher education of Great Britain and Ukraine at the administrative and managerial level.

So, in Great Britain Department for Education is responsible for general management and strategic planning of the higher education system. Partly the duties of Department are delegated to governing bodies of England, Wales, Scotland and Northern Ireland. Financing bodies are also regionalized. In addition, in all higher education institutions of the country there is a special system of self-government and self-control, according to which important, principle decisions are taken at the level at which they should be implemented (The National Archives, n.a.). Thus, we can conclude that British higher education management is based on the principles of decentralization. Instead, in Ukraine, higher education administration is carried out by the Cabinet of Ministers of Ukraine, central executive authorities in the field of education and science, the National Academy of Sciences of Ukraine and national, branch academies of sciences, etc., therefore it is centralized (Tretko, 2014). In our opinion, this is the most significant difference in organization of higher education management in both countries at the administrative and managerial level.

Another distinguishing feature of the British model of education management is the great number of specialized intermediary organizations (Quality Assurance Agency, Higher Education Statistics Agency, British Accreditation Board, etc.). In addition to their direct functions of studying, coordinating and evaluating the activities of universities, they fulfill the strategic objectives defined by Department for Education. Although the institutional distance between the intermediary bodies and the state authorities is clearly established, lately these organizations have been largely influencing central government policy. 
In Ukraine, the National Agency for Quality Assurance in Higher Education was established in 2015 and officially began its activities in 2016. Positive steps of the Agency's activity are participation in the meeting of the Committee on International Cooperation of the National Agency for Quality Assurance in Higher Education. Among the first objectives is clear determination of the needs of other committees in terms of studying international experience and attracting relevant foreign experts; systematization of the results of international projects in the field of higher education quality implemented or being implemented in Ukraine, etc. (Osvitnii portal "Pedahohichna presa", 2016). It should be noted that the adoption of the Law on Higher Education in Ukraine in 2014 was a real impetus towards "europeanization", since higher education institutions were granted the right to academic, economic and financial autonomy.

Research fidnings prove that the laws regulating higher education in Great Britain include the Education Reform Act 1988, the Further and Higher Education Act 1992, The Further and Higher Education (Scotland) Act 1992, the Higher Education Act 2004 (The National Archives, n.a.).

In our view, the system of legislative regulation of higher education in Ukraine has much in common with the British system. During the first years of independence Ukraine existed under the legislative acts of USSR, in particular, the Law of the USSR "On Education" dated May 23, 1991. An important component of the state-building process was the task of forming its own educational policy. The main component of the regulatory framework for reforming higher education in modern Ukraine is the Constitution of Ukraine, the Law of Ukraine "On Education" dated September 5, 2017, the Law of Ukraine "On Higher Education" dated January 7, 2014, the State National Program "On Education (Ukraine of the 21st Century)", the National Doctrine of Education Development, the National Strategy for the Development of Education in Ukraine for 2012-2021. It should be emphasized that the adoption of the new Law of Ukraine "On Education" means creation of an education system of the new generation that "will provide conditions for education of all categories of the population of Ukraine, an effective system of ensuring comprehensive development of people and will contribute to a significant increase in the intellectual, cultural, spiritual and moral potential of society and personality" (Publichnyi audyt, 2017).

Having analyzed the peculiarities of professional training of linguists in Ukraine, we came to the conclusion that in addition to the above-mentioned legal documents, the Regulations "On the Organization of the Education Process in Higher Education Institutions", "On Qualification Levels (Step-by-Step Education)", the Provision "On the Approval of the List of Branches of Knowledge and Specialties for which Higher Education Institutions Train Specialists", drafts of higher education standards, such as 014.02 "Secondary education (language and literature with the indication of language) (bachelor's degree)", 035 “ Philology (humanities) (master's degree)", etc. (Tretko, 2014).

According to D. Edwards (1994), quality is a range of features and characteristics of an item and services that conform to the approved norms (standards). That is, in the field of higher education, quality implies the indicators of the level of knowledge, abilities, skills, professional mastery of British universities that are responsible for "state educational standards", which are also "approved norms". However, in Great Britain, under the autonomy there is no single normative framework or system of the state regulation of the content of student training, unified demands for all university graduates, since each university approves its own curricula, introduces its own organization of the education process and the system for assessing students' knowledge. So, in Great Britain there is no single national programme for training linguists. 
In 2002, the Quality Assurance Agency developed Subject Benchmark Statement for Linguistics (bachelor's degree). The second edition of the document took place in 2007, the third - in September 2015. It should be noted that this document is of a purely advisory nature (Quality Assurance Agency, 2007; 2014; 2015).

Of practical interest is comparative analysis of the structural, content, organizational and pedagogical principles of professional training of future linguists at British and Ukrainian universities, which proves the existence of both common and different approaches. It has been revealed that at the present stage, the main trends in higher education of Great Britain and Ukraine are diversification, centralized and decentralized management, internationalization, social partnership, informatization, competency-based approach, interdisciplinary approach, universalization, individualization (Cunningham, 2014; Gretchenko, \& Gretchenko, 2016). The common approach of both countries is the desire to form a system of linguists' professional training based on the national traditions with the requirements of integration and globalization processes. The possibility of synthesis of these two aspects is aimed at forming a modern linguist capable of generating new ideas, carrying out professional activities under the conditions of sustainable development and information technologies, knowledge transfer, multiculturalism.

It should be noted that since the foundation of the Quality Assurance Agency in 1997 and the approval of the 2000 National Code of Practice for Academic Quality and Standards in Higher Education, systematic measures have been taken to modernize technologies of ensuring higher education quality in Great Britain. However, quality of professional training is seen by British educators not only as a ratio of "goals and outcomes", but also as a functioning quality system. Quality system indicators are identical in many countries: quality of applicants, quality of studentship, quality of teaching staff, quality of educational and methodological support, quality of facilities and appliances. These indicators also correlate with the indicators of UNESCO (Gretchenko \& Gretchenko, 2016).

As noted above, British higher education institutions are empowered to independently develop curricula. Thus, universities engage teaching staff in development of curricula, syllabi, as well as modules for professional training of future specialists. Developers of curricula for professional training of linguists use Subject Benchmark Statement for Linguistics (Q100), the Framework for Higher Education Qualifications in England, Wales and Northern Ireland, the Framework for Qualifications of Higher Education Institutions in Scotland (for Scottish universities). General provisions for development and approval of curricula are set out in Chapter 1 of the Quality Code for Higher Education developed by the Quality Assurance Agency. All the documents, which form the basis of organization of the education process of linguists' training, contain clearly defined strategic goals and objectives for their professional training (Hudson, 2004). It should be noted that Great Britain has a well-developed system for providing applicants with necessary data on curricula. For instance, the Universities and Colleges Admissions Service (UCAS) annually publishes reports on the number of enrollments of applicants; in addition, it processes applicants' applications, thereby contributing to efficiency of the admission system. UNISTATS and Postgraduate Search provide detailed information on curricula at all levels of higher education, allow one to read reviews by other students and compare official information about the courses offered by universities and colleges. Unfortunately, such effective services for higher education are not yet available in Ukraine.

A positive aspect in the process of modernizing the system of higher education in Ukraine is modification of the classification of higher education levels, in particular 
introduction of junior bachelor, abolition of the "specialist" degree", introduction of doctor of philosophy ( $\mathrm{PhD}$ ) (Ukraintsi Sohodni, n.a.). We believe that this is an important step towards the transition from the Soviet classification to modern European standards.

We share the views of V. Tretko (2014) on the low level of academic mobility of Ukrainian students, in particular students-linguists. As practice shows, British universities offering curricula in linguistics, in particular combined degrees (English, German, Spanish, French, Russian, etc.), provide students with the opportunity to take part in various exchange programs abroad. For example, Lanscaster University maintains close partnerships with three universities - the University of Ghent (Belgium), the Beijing Institute of Foreign Studies (China), the Chile-British University of Culture (Chile); the University of Edinburgh collaborates with universities in the USA, Australia, New Zealand, Asia, etc. Instead, most Ukrainian universities can offer students only double degree programmes (in particular, in Poland, due to the territorial closeness of both countries), or the Work and Travel programme that is extremely popular among students, which, in our opinion, is not a very successful example of student mobility, since it involves acquisition of life skills rather than academic ones, which in this context play a more important role, because they are related to professionalism of future specialties. Given the integration processes taking place in the academic community of Ukraine, special attention should be drawn to the fact that compliance with the European standards will, to some extent, require Ukrainian universities to expand geography of mobility of students and teaching staff, and now it involves certain challenges for the higher education system of Ukraine.

The next positive point is that now in Ukraine, master programmes operate independently of bachelor programmes and involve one to two years of study, depending on the specialty, curriculum and university. At British universities it is not obligatory to obtain a bachelor's degree in Linguistics in order to pursue a master's degree in this subject. As you can see, British and Ukrainian approaches to organizing admission to master programmes in Linguistics do not differ from Ukrainian ones.

The essential difference between educational curricula for linguistics in the Great Britain and Ukraine is the level of specialization. Thus, the British system of professional training of bachelors in Linguistics combines wide- and narrow-profile programmes that involve training of specialists in various fields (linguistics, cognitive linguistics, language and linguistics, linguistics and philosophy, linguistics and psychology, linguistics and sociology, linguistics and history, linguistics and economics, linguistics and geography, linguistics and the media, linguistics and music, linguistics and journalism, etc.). In Ukrainian higher education such specializations are not common.

So, we have analyzed the peculiarities of curricula for bachelor's degree in Philology at Khmelnytsky National University (Faculty of International Relations) and bachelor's degree in Linguistics at Newcastle University (School of English Literature, Language, and Linguistics). In accordance with the requirements of the Bologna Declaration, the education process in both institutions is based on credit-based modular principles. In Ukraine, professional training of Bachelors in Philology (applied linguistics) encompasses the study of 53 academic disciplines, of which $62 \%$ are professional disciplines and are normative in nature, that is, compulsory (Fundamentals of Computer Science and Technology, Fundamentals Applied Linguistics, Modern English, Practical English Grammar, Practical English Phonetics, Fundamentals of Programming, Information Technologies in Linguistics, Fundamentals of Text Linguistic Analysis, Automatic Systems of Text Information Translation, Communicative Linguistics, Organization of Databases and Knowledge, Information Resource Support of 
Linguistic Activity, Contrastive Linguistics, Psycholinguistics, Automatic Processing of Natural Language, Pragmatics, Political Linguistics, etc.). The total number of credits is 240 , including 231 credits for compulsory and optional modules, 3 credits - for computerbased practice, 3 credits for computer-based linguistic practice, 3 credits - for certification exam (Khmelnytskyi natsionalnyi universytet, 2017).

At Newcastle University, bachelor's degree in Linguistics consists of only 9 required modules (The Nature of Language, Language Through Time: Introduction to the History of English, Shaping Sounds and Syntax, Buiding Blocks of Language, Language Across Space: Introduction to English Dialects, Phonological Theory, The Syntax of the World's Languages, Syntactic Theory, Extended Study 1: Linguistics and English Language, Extended Study 2: Linguistics and English Language). The total number of credits is 360 CATS, corresponding to 180 ECTS credits. Of these, 140/70 credits are allocated to the study of compulsory disciplines, 220/110 - optional disciplines. It should be noted that in the third year of study at Newcastle University professional training of Bachelors in Linguistics involves studying only optional modules, which, in turn, are also classified. In addition, a bachelor thesis (40/20 credits) is not a prerequisite, which is common to both universities (Newcastle University, 2017).

In addition, the content of programmes for professional training of Bachelors of Linguistics at these universities is also different. Thus, at Khmelnytskyi National University bachelors-linguists must possess communicative, linguistic, information, analytical thinking, scientific, value-based competencies. In addition to linguistic and communicative competencies, Newcastle University encourages continuing development of professional competency (such modules as Career Development for Second Year Students, Developing Enterprise, Entrepreneurship and Employbility, Career Management). A considerable advantage is development of sociocultural competency of future specialists (Language Development: CrossDisciplinary approaches, Sociolinguistics and the Sociology of Language). In our opinion, positive aspect of bachelors' professional training at Khmelnitsky National University is compulsory completion of computer-based and linguistic practice, which promotes development of information, computer and analytical competencies of future specialists.

At Khmelnytsky National University, training of Bachelors in Linguistics involves providing them with the opportunity to work as translators/interpreters, as evidenced by the presence in the curriculum of such disciplines as Theory and Practice of Translation (English) (6 credits), Theory and Practice of Translation (German) (6 credits), Automatic Systems for Text Information Translation ( 6 credits); programmers, developers of linguistic databases, compilers of electronic catalogues - Fundamentals of Computer Science and Technology ( 7 credits), Fundamentals of Programming (7 credits), Mathematical Logic (6 credits), Organization of Databases and Knowledge (6 credits), Object-Oriented Programming (5 credits) (Bidyuk, 2013).

At Newcastle University, students have wide opportunities to obtain two specializations, such as Linguistics with Chinese or Japanese BA Honours, Linguistics with French BA Honours, Linguistics with German BA Honours, Linguistics with Spanish BA Honours, Modern Languages with Linguistics BA Honours. In addition, the University offers a wide range of master programmes, including English Language with/or Linguistics MLitt, Linguistics (with specialist pathways in English Language, Language Acquisition and European Languages MA), Applied Linguistics and TESOL MA, Applied Linguistics (Research) MA, Cross-Cultural Communication and Applied Linguistics MA, Modern Languages MPil, Sociolinguistics (Research) MA, Speech and Language Sciences MPil. 
Based on comparison of the structure of syllabi, it has been found that the syllabi of both universities cover normative (compulsory) and optional units. It is worth noting that both units are different, yet similar aspects are present, too. Thus, in these syllabi, technology is provided exclusively for training future specialists, and general scientific and additional training are beyond. The cycle of humanities and social sciences provides the students with fundamental knowledge, teaches them to navigate in a constantly growing amount of scientific knowledge, the opportunity and knowledge of social interaction; a cycle of general professional and special disciplines - with professional mastery and the opportunity to exercise, if possible, professional mobility.

We emphasize that optional disciplines are important components of the curriculum. So, the number, the list and the names of the disciplines vary considerably, which can be explained by the difference in a conceptual vision of the profession of linguist in Great Britain and Ukraine, as well as the needs of the society of both countries for implementing this profession in the modern labour market, both at the global and national levels.

As one can see, Ukrainian curricula provide fundamental theoretical training that meet global academic challenges, as well as provide the students with practical skills through different types of practice. However, the situation with optional disciplines remains to be complicated, as Ukrainian students are limited in their ability to independently choose optional disciplines that would meet their academic demands, therefore, they are not in a position to independently design their own learning trajectory. In our opinion, this aspect requires a gradual solution, since it is possible to popularize the sector of national higher education not only in Ukraine but also abroad.

By comparing volumes of annual academic load of bachelor curricula, we have concluded that at British universities only $18-20 \%$ are allocated to classroom studies, $78-80 \%$ - to independent study. In Ukrainian higher education, this figure is significantly lower, however, over the past few years there has been a trend towards gradually increasing the time spent on independent study, in particular through distance learning. It should be noted that Ukrainian students do not yet have the skills of independent study, therefore, in our opinion, it is expedient to introduce special courses on the development of learner autonomy.

\section{CONCLUSIONS}

So, we have performed comparative analysis on professional training of linguists at British and Ukrainian universities at administrative and managerial, legislative, organizational and pedagogical, systemic, conceptual, socioeconomic levels. As evidenced above, British and Ukrainian systems of professional training of linguists differ significantly, but simultaneously they are similar to the trends in development. In the first place, the main difference is manifested in the content of curricula. Professional training of linguists in Ukraine is aimed primarily at professional orientation on the national (regional) labour market, comprehensive development of personality of future specialists, formation of harmonious development of both general and professional qualities. In British experience, this training is oriented toward the world labour market. In view of the above, it is expedient to update the content of curricula for linguistics, in particular, its focus on professional and research-based training, taking into account the best practices of foreign experience, in particular British one. An important objective of Ukrainian higher education institutions is to improve quality of teaching professional and special disciplines, provide modern teaching materials, as well as attract foreign specialists to teaching. It is also worthwhile to encourage students to participate in work placements abroad, as it is the case with leading universities in Great Britain. Perspectives for further researches are seen in studying foreign experience in 
training linguists at leading European universities in order to justify the best aspects of such experience and therefore implement them into practice of professional training of linguists at Ukrainian universities.

\section{REFERENCES}

1. Bidyuk, N. (2013). Kontseptualni zasady profesiinoi pidhotovky fakhivtsiv z prykladnoi linhvistyky. Porivnialna profesiina pedahohika, 2, 105-116.

2. Cunningham, B. (2014). Professional life in modern British higher education. London: Institute of Education Press (IOE Press).

3. Edwards, D. J. (1994). Observations on measuring quality in higher education. Education Today, 44 (2).

4. Gretchenko, A. I., \& Gretchenko, A. A. (2016). Bolonskii protsess: integratsiia Rossii v evropeiskoe i mirovoe obrazovatelnoe prostranstvo. Retrieved from https://play. google.com/books/reader?printsec $=$ frontcover\&output $=$ reader\&id $=s i 7 i C w A A Q B A J \& p g=G$ BS.PT4.

5. Hudson, R. (2004). Why education needs linguistics (and vice versa). Journal of Linguistics, 40 (1), 105-130.

6. Khmelnytskyi natsionalnyi universytet. (2017). Kafedra praktyky inozemnoi movy ta metodyky vykladannia. Retrieved from http://www.khnu.km.ua/angl/entr.htm.

7. Newcastle University. (2017). Linguistics BA Honours. Retrieved from http://ncl.reportlab.com/media/output/q100.pdf.

8. Osvitnii portal "Pedahohichna presa". (2016). Vstup NAZIAVO do Yevropeiskoi asotsiatsii iz zabezpechennia yakosti vyshchoi osvity - priorytet u diialnosti vidomstva. Retrieved from http://pedpresa.ua/174202-vstup-nazyavo-do-yevropejskoyi-asotsiatsiyi-izzabezpechennya-yakosti-vyshhoyi-osvity-priorytet-u-diyalnosti-vidomstva.html.

9. Publichnyi audyt. (2017). Rada ukhvalyla zakon pro osvitu: yaki zminy vnosyt reforma? Retrieved from http://publicaudit.com.ua/reports-on-audit/rada-ukhvalyla-zakonpro-osvitu-yaki-zminy-vnosyt-reforma/.

10. Quality Assurance Agency. (2007). Subject Benchmark Statement. Linguistics. Retrieved from http://www.qaa.ac.uk/en/Publications/Documents/Subjectbenchmark-statement-Linguistics.pdf.

11. Quality Assurance Agency. (2014). UK Quality Code for Higher Education. General Introduction. Retrieved from http://www.qaa.ac.uk/en/Publications/ Documents/ Quality-Code-introduction.pdf.

12. Quality Assurance Agency. (2015). Subject Benchmark Statement. Linguistics. Retrieved from http://www.qaa.ac.uk/en/Publications/Documents/SBS-Linguistics-15.pdf.

13. The National Archives. (n.a.). Education. Retrieved from http://www.legislation. gov.uk/title/education?page $=1$.

14. Tretko, V. (2014). Teoriia i praktyka profesiinoi pidhotovky mahistriv mizhnarodnykh vidnosyn $v$ systemi universytetskoi osvity Velykoi Brytanii. Dys. d-ra ped. nauk. Khmelnytskyi nationalnyi universytet, Khmelnytskyi.

15. Ukraintsi Sohodni. (n.a.). Spetsialistiv ta kandydativ nauk bilshe ne bude: rishennia Ministerstva osvity. Retrieved from http://ukrainians.today/spetsialistiv-bilshe-nebude-rishennya-ministerstva-osvity/. 